\title{
Evolution of the East Asian monsoon and its response to uplift of the Tibetan Plateau since 1.8 Ma recorded by major elements in sediments of the South China Sea
}

\author{
MENG XianWei ${ }^{1 *}$, XIA Peng ${ }^{1,2}$, ZHENG Jun $^{1} \&$ WANG XiangQin ${ }^{1}$ \\ ${ }^{1}$ First Institute of Oceanography, State Oceanic Administration, Qingdao 266061, China; \\ ${ }^{2}$ Ocean University of China, Qingdao 266100, China
}

Received June 24, 2010; accepted October 16, 2010

\begin{abstract}
Evolution of the East Asian monsoon and its response to uplift of the Tibetan Plateau has been investigated in the study of global change. Core sediment samples drilled in the South China Sea during ODP Leg184 are the best materials for studying long-term variability of the East Asian monsoon. R-mode factor analysis of major elements in the fine grain-sized carbonate-free sediments $(<4 \mu \mathrm{m})$ of the upper $185 \mathrm{mcd}$ splice of ODP Site 1146 drilled during Leg184 in the South China Sea shows that $\mathrm{Ti}_{2} \mathrm{TFe}_{2} \mathrm{O}_{3}$, $\mathrm{MgO}, \mathrm{K}_{2} \mathrm{O}, \mathrm{P}, \mathrm{CaO}$, and $\mathrm{Al}_{2} \mathrm{O}_{3}$ are representative of a terrestrial factor. The variation in the terrestrial factor score is subject to chemical erosion in the source region and thus indicates the evolution of the East Asian summer monsoon. The terrestrial factor score has three stepwise decreases at $\sim 1.3 \mathrm{Ma}, \sim 0.9 \mathrm{Ma}$, and $\sim 0.6 \mathrm{Ma}$, indicating the phased weakening of the East Asian summer monsoon is related to wholly stepwise, quick uplifts of the Tibetan Plateau since $1.8 \mathrm{Ma}$. The periodic fluctuation of the terrestrial factor score since $\sim 0.6 \mathrm{Ma}$ indicates that the glacial-interglacial cycles have been the main force driving the evolution of the East Asian monsoon. As in the case of Chinese loess, the long-term evolution of the East Asian monsoon recorded in sediments of the South China Sea reflects a coupled effect of the glacial-interglacial cycle and uplift of the Tibetan Plateau.
\end{abstract}

major element, chemical erosion, glacial-interglacial cycle, uplift of Tibetan Plateau, evolution of the East Asian monsoon

Citation: $\quad$ Meng X W, Xia P, Zheng J, et al. Evolution of the East Asian monsoon and its response to uplift of the Tibetan Plateau since 1.8 Ma recorded by major elements in sediments of the South China Sea. Chinese Sci Bull, 2011, 56: 547-551, doi: 10.1007/s11434-010-4258-1

The coupled effect of tectonic uplift and glacial-interglacial cycles on the global climate system is an important theme in the study of global change [1]. Therefore, there has been increasing interest in the uplift of the Tibetan Plateau in the study of global change because of its important role in the formation and evolution of the East Asian monsoon [2-4]. In particular, there has been a focus on the relationship between the wholly stepwise, quick uplift of the Tibetan Plateau and the instability of the East Asian climate since the Quaternary [4-9]. Chinese loess clearly records tectonoclimatic cycles with quasi-periods of 1.2 and $0.4 \mathrm{Ma}$, which are superposed on glacial-interglacial cycles [10,11], and reveals a close link between the wholly stepwise, quick uplift

*Corresponding author (email: mxw@fio.org.cn) of the Tibetan Plateau and the evolution of the East Asian monsoon since the Quaternary. On the other hand, studies on the East Asian monsoon in the South China Sea, using core sediments drilled in ODP Leg 184, have found little association between the long-term evolution of the East Asian monsoon and the uplift of the Tibetan Plateau and have related the evolution of the East Asian monsoon only to glacial-interglacial cycles. In particular, there has been no study on the relationship between the evolution of the East Asian monsoon and the wholly stepwise, quick uplift of the Tibetan Plateau since the Quaternary in the South China Sea [12-14]. In our study, therefore, we compare the stepwise changes of the terrestrial factor, which was extracted from major-element data of fine grain-sized carbonate-free sediments $(<4 \mu \mathrm{m})$ of the upper $185 \mathrm{mcd}$ (meters composite 
depth; corresponding to $1.81 \mathrm{Ma}$ [15]) splice at ODP Site 1146 drilled during Leg184 in the South China Sea using $\mathrm{R}$-mode analysis, with the tectonoclimatic cycles revealed by the magnetic susceptibility of Chinese loess.

\section{Materials and analytical techniques}

Core sediments are from ODP Site 1146, which is located at $19^{\circ} 27.40^{\prime} \mathrm{N}, 116^{\circ} 16.37^{\prime} \mathrm{E}$ and a water depth of $2092 \mathrm{~m}$ (Figure 1). Following the oxygen isotopic curve of planktonic foraminifera [16], samples were taken for majorelement analysis of the upper 185 mcd splice, which was constructed by making three holes (1146A, 1146B and $1146 \mathrm{C})$ at average intervals of $1.1 \mathrm{~m}$. A total of 167 samples were collected. The fine grain-sized fraction $(<4 \mu \mathrm{m})$ was separated from bulk samples for chemical analysis.

Before chemical analysis, the fine grain-sized sediments were dipped in $0.25 \mathrm{~mol} / \mathrm{L} \mathrm{HCl}$ for $1 \mathrm{~h}$, and then iteratively filtrated and rinsed with distilled water for three times to remove the biogenic carbonate [17]. Finally, the carbonatefree sediments were dried and ground to less than 200 mesh for major-element measurement. The concentrations of major elements were determined by the inductively coupled plasma-optical emission spectrum at the Institute of Geophysical and Geochemical Exploration, CAGS. Three national sediment standards were used to ensure analytical precision during the analysis, and the relative error of the

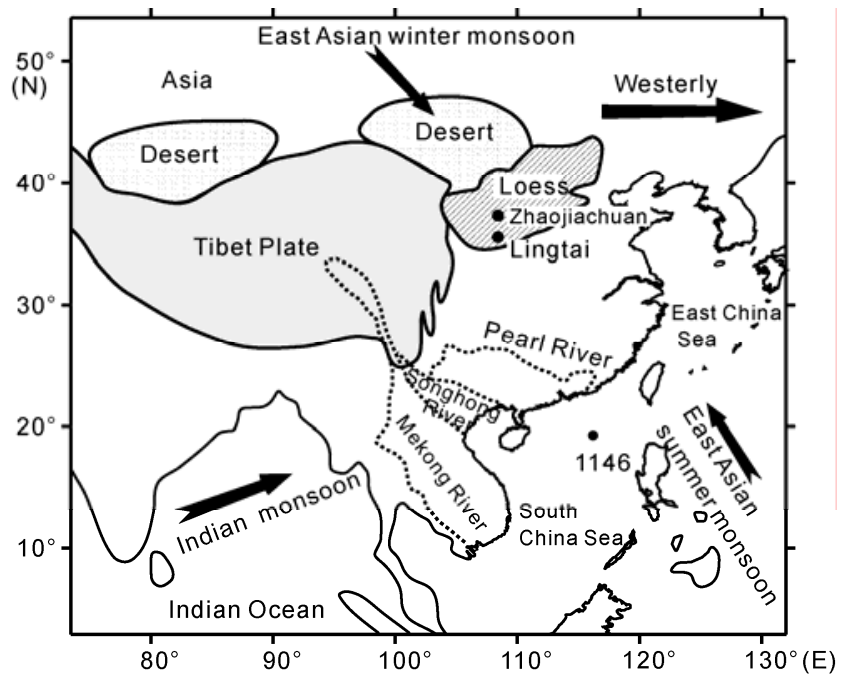

Figure 1 Schematic map showing the locations of ODP Site 1146 and two reference sections of Chinese Loess, and the current pattern of the East Asian monsoon. measured value to the standard value for each element was calculated as between $1 \%$ and 5\%. R-mode analysis was performed using STSS13.0 software, and the terrestrial factor score was subsequently calculated after extraction based on element association. Both the age model and oxygen isotopic data of benthic foraminifera were directly referenced from Clemens et al. [15].

\section{Results}

Under a condition of $80 \%$ cumulated variance in R-mode analysis, three factors, F1, F2 and F3, which are characterized by different major-element associations were obtained. The element association represented by each factor is as follows (Table 1). Factor F1 is predominantly characterized by $\mathrm{P}, \mathrm{Ti}, \mathrm{TFe}_{2} \mathrm{O}_{3}, \mathrm{MgO}$, and $\mathrm{K}_{2} \mathrm{O}$, and to a lesser degree, by $\mathrm{Al}_{2} \mathrm{O}_{3}$ and $\mathrm{CaO}$; factor $\mathrm{F} 2$ is characterized by $\mathrm{Na}_{2} \mathrm{O}$ and $\mathrm{Al}_{2} \mathrm{O}_{3}$; factor $\mathrm{F} 3$ is representative of $\mathrm{Mn}$.

The scores of the three factors are presented in Figure 2. Because each factor is representative of its element association, the variation in the factor score reflects of the variation in the element association. From Figure 2, it is seen that the variation in $\mathrm{F} 1$ characterized by $\mathrm{P}, \mathrm{Ti}, \mathrm{TFe}_{2} \mathrm{O}_{3}, \mathrm{MgO}, \mathrm{K}_{2} \mathrm{O}$, $\mathrm{Al}_{2} \mathrm{O}_{3}$, and $\mathrm{CaO}$ is rather different from variations in $\mathrm{F} 2$ and $\mathrm{F} 3$, exhibiting superposition of a cycling trend and stepwise decreases at $\sim 1.3 \mathrm{Ma}, \sim 0.9 \mathrm{Ma}$, and $\sim 0.6 \mathrm{Ma}$. In particular, the cycling trend has been more prominent since 0.6 Ma. The variations in F1 and F2 are approximately the same, with a stable trend prior to $0.6 \mathrm{Ma}$ and marked fluctuation after 0.6 Ma.

\section{Discussion}

\subsection{Extraction of the terrestrial factor for fine grain- sized carbonate-free sediments}

Because biogenic carbonate has been removed from the fine grain-sized sediments, it is generally accepted that residual carbonate-free detritus consists of silicate, a small quantity of ferromanganese oxide, and biogenic silicon [12,17], whereas the fine grain-sized silicate detritus is predominantly composed of terrestrial materials from rivers and volcanic ash [14,18-20]. Therefore, three factors were associated with sources according to the geochemical characteristics of major elements and the exclusivity of element association in the geological process. Titanium is a conservative element, and $\mathrm{K}, \mathrm{Fe}, \mathrm{Mg}, \mathrm{Al}$ are closely related to the terrestrial

Table 1 Loads of major elements in carbonate-free sediments taken from ODP Site 1146 for each factor

\begin{tabular}{crrrrrrrrrr}
\hline Factor & $\mathrm{Mn}$ & $\mathrm{P}$ & $\mathrm{Ti}$ & $\mathrm{Al}_{2} \mathrm{O}_{3}$ & \multicolumn{1}{c}{$\mathrm{TFe}$} & $\mathrm{MgO}$ & $\mathrm{CaO}$ & $\mathrm{K}_{2} \mathrm{O}$ \\
\hline $\mathrm{F} 1$ & 0.2060 & 0.7642 & 0.8362 & 0.4560 & 0.8814 & 0.8913 & 0.4648 & -0.1327 \\
$\mathrm{~F} 2$ & -0.5606 & -0.2774 & -0.0778 & 0.6041 & -0.2144 & 0.0331 & 0.3422 & 0.6698 \\
F3 & 0.7342 & 0.3788 & -0.2667 & 0.0586 & -0.0838 & -0.1272 & 0.3080 & 0.5587 & -0.1417 \\
\hline
\end{tabular}




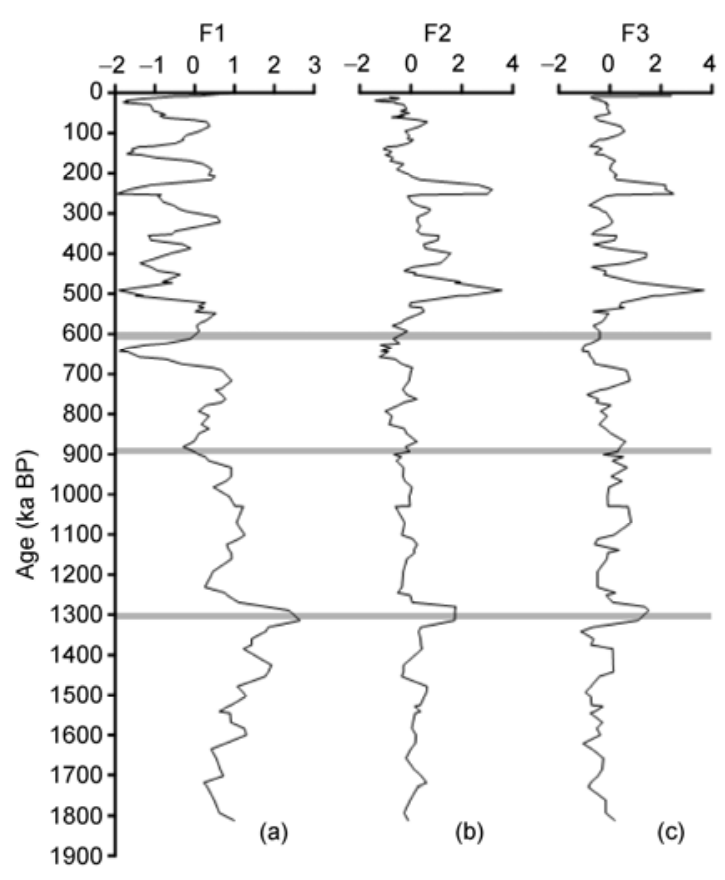

Figure 2 Variations in the terrestrial factor (a), volcanic factor (b), and diagenetic factor (c) of fine grain-sized carbonate-free sediments of the upper $185 \mathrm{mcd}$ splice of ODP Site 1146.

source [18-20]; thus, the association reflected by F1 is of terrene nature (i.e. F1 is a terrestrial factor). The association of $\mathrm{Al}$ and $\mathrm{Na}$, reflected by $\mathrm{F} 2$, implies that for fine grain-sized carbonate-free sediments of the upper splice of ODP Site 1146, Al is closely related to $\mathrm{Na}$ and its concentration is probably affected by a factor other than the terrestrial source; the high concentration of $\mathrm{Al}$ is referred to as "excess Al" [21]. The Al/Ti ratio (up to 46.8) of fine grain-sized carbonate-free sediments of the upper splice of ODP Site 1146 is markedly greater than that of sediments of the Pearl River (19.85), illustrating the existence of "excess $\mathrm{Al}$ " in the fine grain-sized carbonate-free sediments of the upper splice of ODP Site 1146.

Pattan et al. [22] attributed "excess Al" in deep-sea sediments to biogenic silicon and volcanic ash. However, for the core sediments of the ODP Site 1146, the correlation coefficient between aluminum and biogenic silicon, the concentration data of which was cited from Clemens et al. [15], is just 0.3 , indicating that there is no remarkable relationship between biogenic silicon and $\mathrm{Al}$ and that the "excess Al" is not biogenic. In fact, volcanic glass in sediments from the northern slope of the South China Sea has a greater $\mathrm{Al} / \mathrm{Ti}$ ratio of up to 226 and concentrates $\mathrm{Na}_{2} \mathrm{O}$ [23]. It can thus be concluded that "excess Al" in the fine grain-sized sediments of the upper splice of ODP Site 1146 is of volcanic origin, and F2 characterized by $\mathrm{Al}$ and $\mathrm{Na}$ is a volcanic factor. Manganese is a typical autogenic element resulting from early diagenesis, and F3 characterized by Mn is an early diagenetic factor.

\subsection{Implications of the terrestrial factor for the evolu- tion of the East Asian summer monsoon}

One effect of the evolution of the East Asian monsoon is chemical weathering in the source region, and the monsoon thus controls the supply of terrestrial materials to the seabed. The enhancement or weakening of the summer monsoon can result in intensive or weak chemical erosion in the source region, and consequently, the proportion of terrestrial material in marine sediments increases or decreases. Contrarily, the variation in the terrestrial factor for marine sediments could reflect the intensity of chemical weathering in the source region and thus reveal the evolution of the summer monsoon. An increase or decrease in the fluvial contribution to marine sediments implies the enhancement or weakening of chemical weathering and consequently the summer monsoon [18-20,24,25]. Concerning the fine grain-sized carbonate-free sediments of the upper splice of ODP Site 1146, because the factor loads of the terrestrial elements and oxides $\mathrm{P}$, $\mathrm{Ti}, \mathrm{TFe}_{2} \mathrm{O}_{3}, \mathrm{MgO}, \mathrm{K}_{2} \mathrm{O}, \mathrm{Al}_{2} \mathrm{O}_{3}$, and $\mathrm{CaO}$ in $\mathrm{F} 1$ are all positive, an increase or decrease in the F1 factor score would mean an increase or decrease in the fluvial contribution to the total sediments. This would imply enhancement or weakening of chemical erosion in the source region and ultimately indicate the evolution of the East Asian summer monsoon.

\subsection{Relationship between the evolution of the East Asian summer monsoon and glacial-interglacial cycles}

Comparison of the variation in the terrestrial factor with the variations in the oxygen isotopes of benthic foraminifera clearly shows that the cycling variation of the terrestrial factor of the fine grain-sized sediments of the upper splice of ODP Site 1146 perfectly matches the glacial-interglacial cycles recorded by oxygen isotopes (Figure 3(a),(b)). The fluvial contribution increased in interglacial periods and decreased in glacial periods, indicating that the East Asian summer monsoon strengthened in interglacial periods and weakened in glacial periods. We thus conclude that the evolution of the East Asian monsoon was controlled by glacial-interglacial cycles.

\subsection{Relationship between the evolution of the East Asian summer monsoon and the wholly stepwise, quick uplift of the Tibetan Plateau}

In addition to periodic variation, the terrestrial factor score of fine grain-sized carbonate-free sediments of the upper splice of ODP Site 1146 clearly shows a trend of stepwise change (Figure 3(b)); the terrestrial factor score tended to increase in the period from $\sim 1.8 \mathrm{Ma}$ to $\sim 1.3 \mathrm{Ma}$ and subsequently decreased stepwise at $\sim 1.3 \mathrm{Ma}, \sim 0.9 \mathrm{Ma}$, and $\sim 0.6$ Ma. These characteristics indicate chemical erosion, and thus, the East Asian summer monsoon in the source region increasingly strengthened in the period from $\sim 1.8 \mathrm{Ma}$ to $\sim 1.3 \mathrm{Ma}$ and weakened in a stepwise manner at $\sim 1.3 \mathrm{Ma}$, $\sim 0.9 \mathrm{Ma}$, and $\sim 0.6 \mathrm{Ma}$. This stepwise weakening agrees 


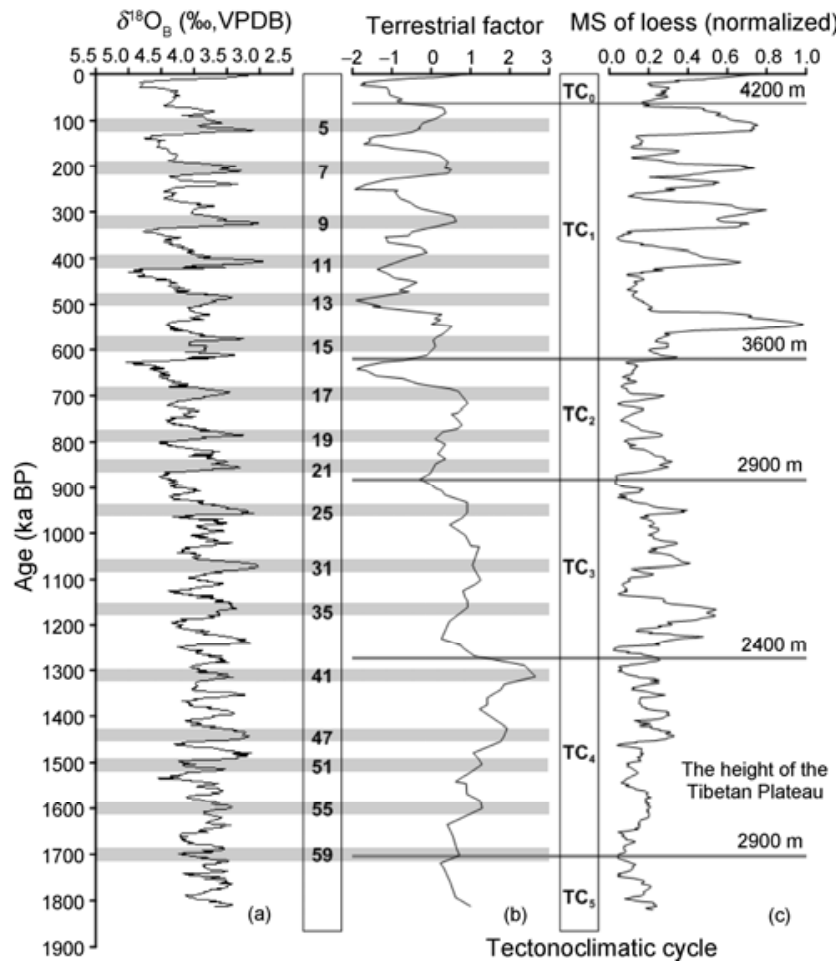

Figure 3 Comparison of the terrestrial factor score of the fine grain-sized carbonate-free sediments of the upper splice of the ODP Site 1146 (b) with the oxygen isotope of benthic foraminifera (a) and stacked magnetic susceptibility of Lingtai and Zhaojiachuan loess (c), showing the relationships of the evolution of the East Asian summer monsoon (b) with glacial-interglacial cycles (a) and the stepwise uplifts of the Tibetan Plateau (c). The oxygen isotopic data of benthic foraminifera and magnetic susceptibility data of Lingtai and Zhaojiachuan loess were cited from Clemens et al. [15].

well with the tectonoclimatic cycles recorded by the magnetic susceptibility of Chinese loess (Figure 3(b),(c)). The stepwise changes of the East Asian summer monsoon occurring in the periods of 1.81-1.3 Ma, 1.3-0.9 Ma, 0.9-0.6 $\mathrm{Ma}$, and $0.6-0 \mathrm{Ma}$, exactly matched the tectonoclimatic cycles of $\mathrm{TC}_{4}, \mathrm{TC}_{3}, \mathrm{TC}_{2}$, and $\mathrm{TC}_{1}$ [8-11]. The results show that just as in the case of Chinese loess, the sediments drilled from the South China Sea are an archive recording the relationship between the evolution of the East Asian monsoon and the wholly stepwise, quick uplift of the Tibetan Plateau since the Quaternary.

Characterized by several events of intensive uplift, the Tibetan Plateau has entered a period of wholly stepwise and quick uplift since the Quaternary [5-8]. Of these events, those occurring at 1.2-1.3 Ma, 0.8-0.9 Ma, and 0.5-0.6 Ma were especially intensive, making the Tibetan Plateau an obstacle that controlled the circulation of the East Asian monsoon [7]. The variation in the terrestrial factor score of the fine grain-sized carbonate-free sediments of ODP Site 1146 also shows the effect of the wholly stepwise, quick uplift of the Tibetan Plateau on the evolution of the East Asian monsoon.

In the period from 1.81 to $1.3 \mathrm{Ma}$, the Tibetan Plateau was in a transition epoch from the formation of the plateau plane to wholly uplift. During the epoch, the average height of the cumulated plateau plane did not increase but decreased from 2900 to $2400 \mathrm{~m}$ [10] as a result of parallel developments of the uplifts of the marginal mountains of the Tibetan Plateau and interior isostatic modulation. Corresponding to the decease in the height of the Tibetan Plateau, the East Asian summer monsoon would have likely strengthened, resulting in more-intense chemical erosion in the source region and thus an increase in fluvial-discharged matter to the South China Sea. This was characterized by a higher terrestrial factor score of the fine grain-sized carbonate-free sediments of the upper splice of ODP Site 1146.

Since $\sim 1.3 \mathrm{Ma}$, the tectonic movement of the Tibetan Plateau has qualitatively shifted from formation of the plateau plane and interior isostatic modulation to wholly stepwise, quick uplift $[6,10]$. The plateau plane rose from 2400 to 2900 to $3600 \mathrm{~m}$ and from 1.3 to 0.9 to $0.6 \mathrm{Ma}$, respectively. The qualitative transition of tectonic movement of the Tibetan Plateau has resulted in an important modulation of the East Asian monsoon circulation from the prevailing of the summer monsoon to the enhancing of the winter monsoon [10]. As the Tibetan Plateau was at a height of $2900 \mathrm{~m}$, most of its surface was in the range of the precipitation maximum, and the Tibetan Plateau was largely in a frozen circle, enhancing the plateau's function as a heat sink. This enhanced the East Asian winter monsoon and ultimately weakened the East Asian summer monsoon. The change in circulation of the East Asian monsoon and induced weakening of the East Asian summer monsoon decreased the intensity of chemical erosion, and thus, fluvial terrestrial matter discharged from land to the South China Sea. As a consequence, the terrestrial factor score of the fine grain- sized carbonate-free sediments of the upper splice of ODP Site 1146 decreased. Since 0.6 Ma, during which time the Tibetan Plateau has risen from $3600 \mathrm{~m}$ to $4200 \mathrm{~m}$ to lie above the height range of maximum precipitation, the mutual restriction of the heat-sink function and heat-source function has predominated [11] and antagonism between the East Asian winter and summer monsoons has increased. Incidentally, the climate has become polarized, being extremely dry and cold in glacial periods and extremely wet and warm in interglacial periods [6]. In association with the climatic polarization, the response of chemical erosion in the source region to the glacial-interglacial cycles has become more obvious, which is shown by the greater fluctuation of the terrestrial factor score of the fine grain-sized carbonate-free sediments of the upper splice of ODP Site 1146.

\section{Conclusions}

The major association of $\mathrm{P}, \mathrm{Ti}, \mathrm{TFe}_{2} \mathrm{O}_{3}, \mathrm{MgO}, \mathrm{K}_{2} \mathrm{O}, \mathrm{CaO}$, and $\mathrm{Al}_{2} \mathrm{O}_{3}$ in fine grain-sized carbonate-free sediments of the upper splice of ODP Site 1146 is a terrestrial factor. The variation in the terrestrial factor score reflects the change in the contribution of fluvial terrestrial matter to marine sediments and thus could imply a change in intensity of chemical 
erosion in the source region and the evolution of the East Asian summer monsoon. The terrestrial factor score decreased in a stepwise manner at $\sim 1.3 \mathrm{Ma}, \sim 0.9 \mathrm{Ma}, \sim 0.6 \mathrm{Ma}$, but has had dominant periodic fluctuations since $\sim 0.6 \mathrm{Ma}$. The correspondence between the stepwise changes in the terrestrial factor score and the tectonoclimatic cycles recorded by the magnetic susceptibility of Chinese loess indicates that the evolution of the East Asian summer monsoon, recorded by major-element association in the fine grain-sized carbonate- free sediments of the upper splice of ODP Site 1146, is closely related to wholly stepwise, quick uplifts of the Tibetan Plateau. However, since 0.6 Ma, the parallel trends of the terrestrial factor score and the oxygen isotope of benthic foraminifera illustrate that the evolution of the East Asian monsoon has been predominantly controlled by glacialinterglacial cycles. As in the case of Chinese loess, the longterm evolution of the East Asian monsoon recorded in sediments of the South China Sea reflects a coupled effect of the glacial-interglacial cycle and uplift of the Tibetan Plateau.

We thank the ODP Sample Repository for supplying samples for our study. We also thank reviewers for their advice. This work was supported by the National Natural Science Foundation of China (40576034).

1 Raymo T E, Ruddiman W F. Tectonic forcing of late Cenozoic climate. Nature, 1992, 359: 117-122

2 Wang P X. Ocean Drilling Project and Tibetan Plateau (in Chinese). Adv in Earth Sci, 1995, 10: 254-257

3 An Z S. The history and variability of the East Asian paleomonsoon climate. Quat Sci Rev, 2000, 19: 171-187

4 An Z S, Kutzbach J E, Prell W L, et al. Evolution of Asian monsoons and phased uplift of the Himalaya-Tibetan Plateau since Late Miocene times. Nature, 2001, 411: 62-66

5 Xue X X, Yue L P, Zhou J, et al. Susceptibility of the late Cenozoic red earthloess sequence in Xunyi, Shaanxi Province and environmental variation (in Chinese). Quat Sci, 2003, 23: 103-108

6 Ma R Y, Peng J B, Liu L N, et al. Climate and environment effect and tectonic erosionof loess plateau in Qinghai-Xizang Plateau uplift (in Chinese). Res Soil Water Conserv, 2006, 13: 220-225

7 Shen J, Lu H Y, Wang S M, et al. A 2.8 Ma record of environmental evolution and tectonic events inferred from Cuoe core in the middle of Tibetan Plateau. Sci China Ser D-Earth Sci, 2004, 47: 1025-1034

8 Pan B T, Gao H S, Li B Y, et al. Step-like landforms and uplift of the Qinghai-Xizang Plateau (in Chinese). Quat Sci, 2004, 24: 50-57
9 Guo Z T, William F R, Hao Q Z, et al. Onset of Asian desertification by 22 Myr ago inferred from loess deposits in China. Nature, 2002, 416: $159-163$

10 Wu X H, An Z S. Loess-paleosol sequence on Loess Plateau and uplift of the Qinghai-Xizang Plateau. Sci China Ser D-Earth Sci, 1996, 39: 121-133

11 Wu X H, Wang S M, An Z S, et al. On tectonoclimatic cycle ocquasi-period of 1.2 $\mathrm{Ma}$ in late Cenozioc (in Chinese). J Geomech, 1998, 4: 1-10

12 Clemens S C, Murray D W, Prell W L. Nonstationary phase of the Plio-Pleistocene Asian monsoon. Science, 1996, 274, 943-948

13 Wang P X, Jian Z M, Zhao Q H, et al. Evolution of the South China Sea and history of monsoon revealed in deep-sea records. Chinese Sci Bull, 2003, 48: 2549-2561

14 Wan S M, Li A C, Stuut J W, et al. Grain size records of at ODP 1146 from the northern South China Sea: Implications on the East Asian monsoon evolution since $20 \mathrm{Ma}$. Sci China Ser D-Earth Sci, 2007, 50: 1536-1547

15 Clemens S C, Prell W L, Sun Y, et al. Southern hemisphere forcing of Pliocene $\delta^{18} \mathrm{O}$ and the evolution of Indo-Asian monsoons. Paleoceanography, 2008, 23: 1231-1245

16 Clemens S C, Prell W L. Data report: preliminary oxygen and carbon isotopes from site 1146, northern Sourh China Sea. In: Prell W L, Wang P, Blum P, et al., eds. Proc ODP Sci Res, 2003, 184: 1-8

17 Asahara Y, Tanaka T, Kamioka H, et al. Provenance of the north Pacific sediments and process of source material transport as derived from Rb-Sr isotopic systematics. Chem Geol, 1999, 158: 271-291

18 Wei G J, Liu Y, Shao L, et al. Climate records in chemical composition of detritus sediments, the South China Sea (in Chinese). Mar Geol Quat Geol, 2003, 23:1-4

19 Wei G J, Liu Y, Li X H, et al. Major and trace element variations of the sediments at ODP Site 1146, South China Sea, during the last 230 $\mathrm{ka}$ and their paleoclimate implications. Palaeogeogr Palaeoclimatol Palaeoecol, 2004, 212: 313-342

20 Wei G J, Li X H Liu Y, et al. Geochenmical record of chemical weathering and monsoon climate change since the early Miocene in the South China Sea. Paleoceanography, 2006, 21: 1-11

21 Wei G J, Liu Y, Li X H, et al. Discussion on excess aluminum in sediments from the South China Sea (in Chinese). Bull Mineral Petrol Geochem, 2003, 22: 23-25

22 Pattan J N, Shane P. Excess aluminum in deep sea sediments of the central Indian Basin. Mar Geol, 1999, 161: 247-255

23 Liang X R, Wei G J, Shao L, et al. Records of Toba eruptions in the South China Sea-Chemical characteristics of glass shards from ODP 1143A. Sci China Ser D-Earth Sci, 2001, 44: 871-878

24 Wang C, Gong Q J, Li G, et al. Changes in chemical erosion in source region deduced from major element ratios in sediments from the South China Sea (in Chinese). Mar Geol Lett, 2007, 23: 1-5

25 Liu Z F, Trentesaux A, Clemens S C, et al. Clay mineral assemblages in the northern South China Sea: Implications for East Asian monsoon evolution over the past 2 million years. Mar Geol, 2003, 201: 133-146

Open Access This article is distributed under the terms of the Creative Commons Attribution License which permits any use, distribution, and reproduction in any medium, provided the original author(s) and source are credited. 